\title{
A Rare and Fatal Complication of Tracheostomy: Tracheo-Innominate Fistula, A Case Report and Literature Review
}

\author{
*Salama Khadija, Merzouqi B, El Hafed R, Rouadi Sami, Abada RA, Roubal M and Mahtar M \\ ENT-HNS Department, Casablanca, Morocco
}

Submission: November 19, 2018; Published: November 29, 2018

*Corresponding author: Salama Khadija, ENT-HNS Department, Casablanca, Morocco

\section{Introduction}

The tracheo-innominate fistula (TIF) is a fistulous communication between the trachea and the innominate artery. A classic but rare complication, affecting $1 \%$ of patients with tracheostomy tube $(1,2)$. It causes massive intratracheal hemorrhage which immediately causes a double hemodynamic and respiratory distress. This pathology is spontaneously fatal in few minutes if not recognized and immediately managed. In 1980s, the risk of injury of a large vessel by a tracheostomy cannula was estimated at $2 \%$ [1]. Currently this risk is estimated at $0.3 \%$ [2]. We report a case of TIF in a 5-year-old girl in whom surgical management by immediate sternotomy allowed her survival. We discuss through this case and a review of the literature the physio-pathological, clinical, therapeutic and preventive aspects of this life-threatening complication.

\section{Case Report}

A 5-year-old girl with severe lead neuropathy who required tracheostomy following a prolonged intubation, presented a massive hemoptysis on the $20^{\text {th }}$ day of tracheotomy. Temporary hemostasis was achieved by immediate over-inflation of the tracheostomy tube cuff. Surgical exploration under general anesthesia was performed with the presence of both ENT and cardiovascular surgeons. Through median sternotomy, we found a tracheal defect and innominate artery fissure. Hemostasis was ensured by suture of the vascular lesion. The tracheal defect was reconstructed by muscular flap. Postoperatively, the patient was monitored in the intensive care unit, her hemodynamic and respiratory status were stabilized, with no remarkable rebleeding. One week later, the patient died due to worsening of her neurological, hemodynamic and respiratory status.

\section{Discussion}

Tracheo-innominate fistula is a tracheostomy complication that was first described in 1879 [2]. It results from a conflict between the anterolateral wall of the trachea (injured by the cannula) and the posterior surface of the innominate artery. The peak of incidence is between the $7^{\text {th }}$ and the $14^{\text {th }}$ day after tracheostomy procedure [3,5]. It occurs sometimes later, 20 days later in our case, due to a progressive erosion of the anterior wall of the trachea by the cannula. Many factors may predispose to the development of TIF including a low placement of tracheostomy (below the third tracheal ring), prolonged overpressure of the cuff resulting in local necrosis, excessive anterior concavity of the cannula or its repeated mobilizations [4]. Other factors may be associated: local ischemia, infection or prolonged use of steroids or immunosuppressants $[4,6]$. The diagnosis of TIF in patients with tracheostomy should be evoked in the event of the ejection of small amount of bleeding called the sentinel or herald bleed that occurs 24 to 48 hours before the occurrence of massive pulsatile bleeding from around the tracheostomy site and / or from the upper airways. The pulsatility of the cannula is also a very evocative sign [7-9] (Figure 1).

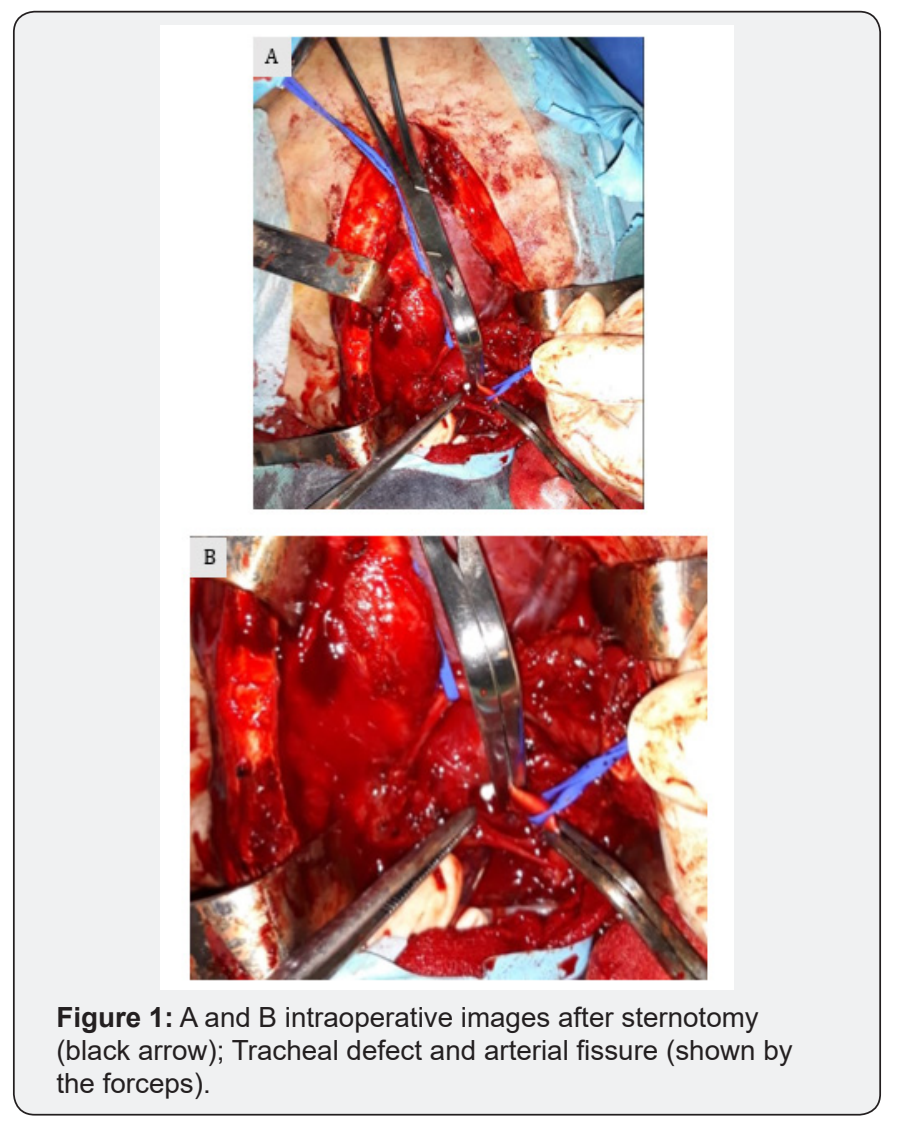




\section{Global Journal of Otolaryngology}

In our case, the arterial character of the hemorrhage was undoubted because of the strongly pulsating bleeding and the bright red color of the blood. Immediate hemostasis is the main priority, it can be achieved by either an over-inflation of the tracheostomy tube cuff in place or replacing it with a cuffed endotracheal tube to compress the fistula [2] and to protect airway in order to prevent respiratory distress. The definitive treatment of TIF requires median sternotomy and innominate artery ligation. Complete median sternotomy has traditionally been the most common approach for TIF repair (10). However, surrounding tissues may be contaminated by tracheal secretions and the surgical technique may be hampered by tissue inflammation resulting in an increased rate of local infection postoperatively Recently, endovascular approaches have been used to treat various arterial hemorrhages. Endovascular techniques are less invasive than open surgery, usually with a shorter recovery period [10].

\section{Conclusion}

The ulceration of the innominate artery by a tracheostomy cannula is a very serious complication that must be known by all medical and paramedical staff in charge of patients with tracheostomy. Premonitory signs, even if not very specific, must be known and prompt a pre-established management procedure. The curative procedure that is unlikely to be delayed is an open sternotomy exploration.

\section{References}

1. Quinio P, Lew Yan Foon J, Mouline J, Braesco J, De Tinteniac A (1995) Ulcération du tronc brachiocéphalique par une canule de trachéotomie. Ann Fr Anesth Reanim 14(3): 296-299.

2. Shingo Hamaguchi, Yasuo Nakajima (2012) Two cases of tracheoinnominate artery fistula following tracheostomy treated successfully by endovascular embolization of the innominate artery. J Vasc Surg 55(2): 545-547.

3. Quinio P, Lew Yan Foon J, Mouline J, Braesco J, De Tinteniac A (1995) Ulcération du tronc brachiocéphalique par une canule de trachéotomie. Ann Fr Anesth Reanim 14(3): 296-299.

4. Grant CA, Dempsey G, Harrison J, Jones T (2006) Tracheo-innominate artery fistula after percutaneous tracheotomy: three case reports and clinical review. Br J Anaesth 96(1): 127-131.

5. Allan JS, Writh CD (2003) Tracheoinnominate fistula: diagnosis and management. Chest Surg Clin N Am 2003;13(2): 331-341.

6. Jones JW, Reynolds M, Drapanas T (1976) Tracheo-innominate artery erosion: successful surgical management of a devasting complication. Ann Surg 184(2): 194-204.

7. Saleem T, Baril DT, Fistula (2018) Tracheo Innominate Artery. StatPearls. Treasure Island (FL): Stat Pearls Publishing, USA.

8. Toty L, Hertzog P, Diane Ch, Aboudi A (1967) Six cas d'he'morragie mortelle chez des malades trache'otomise's et placés sous ventilation assistée. Ann Chir Thorac Cardiovasc 6: 453-459.

9. Langeron O, Paqueron X, Meneglia R (2001) Complications de l'abord trachéal en réanimation. In: Sfar, editor. Confe'rences d'actualisation. Congrés national d'anesthésie et de reanimation, pp. 597-606.

10. Allan JS, Wright CD (2003) Tracheoinnominate fistula: diagnosis and management. Chest Surg Clin N Am 13(2): 331-341.

\section{Your next submission with Juniper Publishers} will reach you the below assets

- Quality Editorial service

- Swift Peer Review

- Reprints availability

- E-prints Service

- Manuscript Podcast for convenient understanding

- Global attainment for your research

- Manuscript accessibility in different formats ( Pdf, E-pub, Full Text, Audio)

- Unceasing customer service

Track the below URL for one-step submission https://juniperpublishers.com/online-submission.php 